一論 文—

（日本化学会誌，1994，（4)， p. 329 335）

(C) 1994 The Chemical Society of Japan

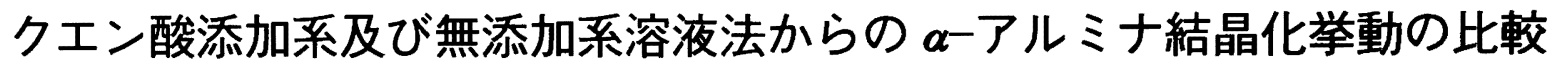

(1993年11月 1 日受理)

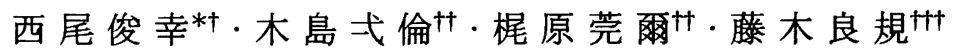

アルミナ前駆体絨維を得るための溶液系

(1) $\mathrm{NCS}$ 溶液 : $\mathrm{Al}\left(\mathrm{OPr}^{\mathrm{i}}\right)_{3}-\mathrm{Al}\left(\mathrm{NO}_{3}\right)_{3}$-クエン酸- $\mathrm{H}_{2} \mathrm{O}$ 系

$\left(\mathrm{Al}\left(\mathrm{OPr}^{i}\right)_{3} \mathrm{~mol} / \mathrm{Al}\left(\mathrm{NO}_{3}\right)_{3} \mathrm{~mol}=2, \mathrm{H}_{2} \mathrm{O} \mathrm{mol} /\right.$ total $\mathrm{Al} \mathrm{mol}=50$, total $\mathrm{Al} \mathrm{mol} /$ クエン酸 $\left.\mathrm{mol}=10\right)$,

(2) $\mathrm{NS}$ 溶液 : $\mathrm{Al}\left(\mathrm{OPr}^{i}\right)_{3}-\mathrm{Al}\left(\mathrm{NO}_{3}\right)_{3}-\mathrm{H}_{2} \mathrm{O}$ 系

$\left(\mathrm{Al}\left(\mathrm{OPr}^{i}\right)_{3} \mathrm{~mol} / \mathrm{Al}\left(\mathrm{NO}_{3}\right)_{3} \mathrm{~mol}=2, \mathrm{H}_{2} \mathrm{O} \mathrm{mol} /\right.$ total $\left.\mathrm{Al} \mathrm{mol}=50\right)$,

に関し,クエン酸の有無が, 溶液構造に如何なる影響を与えるのかを, 小角 X 線散乱測定より検討 した。これより，NCS 溶液及びNS 溶液何れの溶液の場合も濃縮に伴い慣性半径は低下したが，その 割合はクエン酸を含むNCS 溶液の方がクエン酸を含をないNS 溶液より大きく, 紡系可能濃度溶液に おける慣性半径值は前者が50 A, 後者が $100 \AA$ であった.これより, $\mathrm{Al}\left(\mathrm{NO}_{3}\right)_{3}$ に対する $\mathrm{Al}\left(\mathrm{OPr}^{i}\right)_{3}$ の 量が同一であっても, 系にクエン酸を添加した場合と添加しなかった場合で, 溶夜を構成していると考 えられる $\mathrm{Al}$ のクラスター構造が異なると共に，その後の濃縮に対する溶液構造の变化に対しても異な った挙動を示すことが明らかとなった。

これらの溶液より得られたゲル試料を焼成した場合の $\alpha$-アルミナへの結晶化速度を定量的 X 線回折

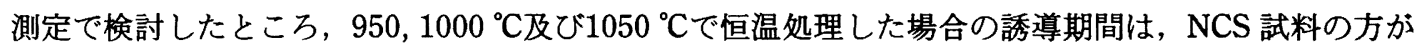
NS 試料より短いことが示された．また, 誘導期間を差し引いた時間と転換率との間で成り立つ Avra$\mathrm{mi}$ 式より得られる反応速度定数と $1 / T$ （処理絶対温度）との Arrhenius プロットより得られた活性化 エネルギーは, NCS 試料の方が NS 試料より若干大きかった.これらは何れも, クエン酸の有無によ る炭素量における違い，及び溶液構造における違いを反映していると考えられる翰燥ゲル試料での構造 の違いが原因していると考えられた．また，Avrami 指数は何れの試料の場合も1.6であり，溶液構造 を反映すると考えられる試料における構造の違いは核形成一成長の様式には影響しないことがわかっ た.

\section{1 緒言}

溶液法によりセラミックスを得る特徵は，合成方法が比較的簡 単であること, 多元素系の場合原子レベルでの混合を制御するこ とにより，目的相を得るための焼成温度を低くできること，ま た, バルク体, 粉体, 膜状物, 紻維状物などの種々の形態で得る ことが比較的容易であることなどと考えられる.

著者らは，多座配位有機酸を用いた溶液系で，これを濃縮する ことにより得られる粘ちょう溶液から容易に前駆体㵶維が得られ

ユニチカ株式会社 中央研究所, 611 宇治市宇治小桜 23

†現在 ユニチ力株式会社宇治工場, 611 宇治市宇治戸の 内 5

\#京都工芸瀻維大学工芸学部物質工学科, 606 京都市左京 区松ヶ崎御所海道町

+11 科学技術庁 無機材質研究所, 305 つくば市並木 1-1

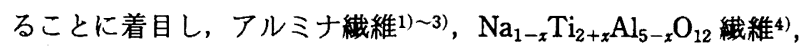
$\mathrm{YBa}_{2} \mathrm{Cu}_{3} \mathrm{O}_{y}$ 織維 5 などの合成につき検討を行ってきた. また，ア ルミナ前駆体㵶維を得るための溶液系で, 多座配位有機酸である クエン酸の有無に起因する溶液構造と电系性の関係につき, ${ }^{27} \mathrm{Al}$ 核磁気共鳴法 (NMR) による解析を行い, $\mathrm{Al}-\mathrm{O}$ 結合の六配 位構造と $\mathrm{Al}^{13+}$ 多核陽イオン $\left(\left[\mathrm{Al}_{13} \mathrm{O}_{4}(\mathrm{OH})_{24}-\left(\mathrm{H}_{2} \mathrm{O}\right)_{12}\right]^{7+}\right)$ の 残留量が曳系性に影響を及ほすことを示した2).

本論文では，まず，アルミナ前駆体織維を得るための溶液系に おけるクエン酸の有無が, 容液構造に如何なる影響を与えるのか を，比較的大きな範用での溶液構造の解析に適した小角 X 線散 乱(SAXS) 測定より検討した。 また，これらの溶液系より得ら れたゲル試料を焼成した場合の $\alpha$ ーアルミナへの結晶化速度が， 溶液構造を如何に反映しているのかに関し, 定量的 X 線回折法 （QXRD）により検討した. 


\section{2 実験方法}

\section{1 試料の調製}

（1）溶液の調製

本研究には下記の容夜系を用いた.

$\mathrm{NCS}$ 容液 : $\mathrm{Al}\left(\mathrm{OPr}^{i}\right)_{3}$ (以下 AIP と略す) $\mathrm{Al}\left(\mathrm{NO}_{3}\right)_{3}$ (以下 $\mathrm{AN}$ と略す) 一クエン酸 $-\mathrm{H}_{2} \mathrm{O}$ 系,

$\mathrm{NS}$ 容液 : AIP-AN- $\mathrm{H}_{2} \mathrm{O}$ 系,

これらの調液方法は前報の方法に準じており，図 1 に調液手 順の概要を示す2).

溶液の合成はまず, $\mathrm{AN} \cdot 9 \mathrm{H}_{2} \mathrm{O}$ を蒸留水に溶解し，これに AIP 粉末を室温で加え, その後 1 日室温にてかきまぜを行う. 更にクエン酸添加系(NCS 溶液) に関しては, 全 $\mathrm{Al}$ モル量の 1 / 10 モル量のクエン酸一水和物をこの溶液に添加し溶解させる. ここで, 何れの溶液系も, AIP mol/ $\mathrm{AN} \mathrm{mol}=2, \mathrm{H}_{2} \mathrm{O} \mathrm{mol} /$ total $\mathrm{Al} \mathrm{mol}=50$ であった．また，濃縮された溶液は何れむ曳系性を 示した.

\section{(2) SAXS 測定試料の作製}

それそれの系に関し最終添加物を溶解した（調夜が終わった） 後, 溶液 $0.5 \mathrm{~g}$ をサンブリングし, $5.0 \mathrm{~g}$ のエタノールで希釈し た. 更に残った溶液を $100{ }^{\circ} \mathrm{C}$ 油浴を用い濃縮してゆき，それそ れ濃縮途中段階の溶液 $0.5 \mathrm{~g}$ をサンプリングし, 濃縮前にサンブ リングされた測定用希釈溶液中の $\mathrm{Al}$ 濃度と同一になるような量 のエタノールで希釈を行った．エタノールを希釈溶液として用い た理由は，一つは，広い濃度範囲に対し安定した希釈溶液が得ら れたためである.これに対し例えばメタノールを用いた場合は逆 に広い濃度範囲において希釈の際ゲル化が起こってしまう。 た，もう一つの理由は，エタノールで希釈された溶液はSAXS 測定に対し2〜3週間保存していても值が安定しているためであ る.ここで, SAXS 測定用試料中の Al 濃度を同一にした理由 は, 系内に存在するクラスターの構造が濃度に依存する場合があ るためである6),7)

この様にして得られた SAXS 測定溶液を, 内径 $1 \mathrm{~mm}$ の石英 キャピラリーに, 底か $515 \mathrm{~mm}$ 気泡を入れる様に満たし， $\mathrm{X}$ 線

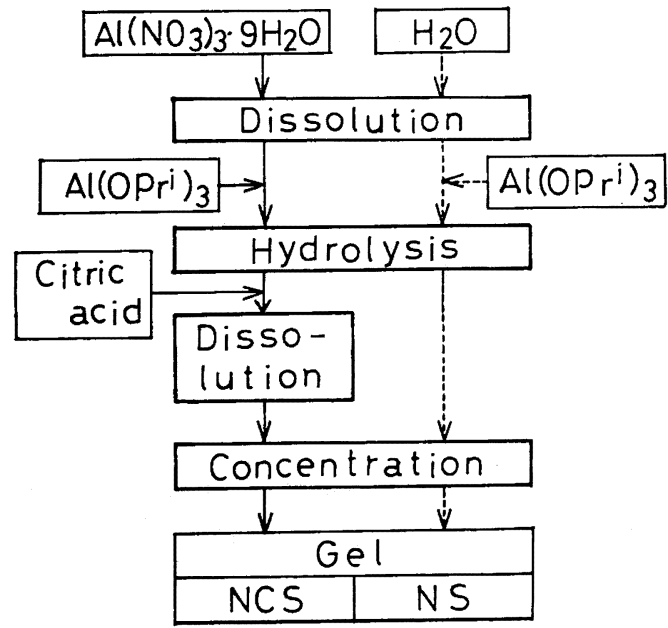

Fig. 1 Fabrication processes of gel specimens
のスリットを溶液の下端に合わせるように用いた。これは，クラ スターなどの沈降による測定部位での微視的な濃度の低下がある 場合その影響を少なくするためである．中た，測定中溶媒の揮発 による濃度変化を防ぐためにキャピラリーのロをフィルムでシー ルした.

(3) QXRD 測定用試料の調製

上記 2. 1(1)項で調製された NCS 溶液及びNS 溶液を， $100{ }^{\circ} \mathrm{C}$ の油浴を用い最終的に乾固するまで濃縮を行った，得られた固化 物は乳鉢ですりつぶし, 更に $105{ }^{\circ} \mathrm{C}$ 乾燥器にて一日乾燥後, 再 度乳鉢ですりつぶしたものを次の実験に用いた。

\subsection{SAXS 測定}

SAXS 測定は理学製 RAD $-\gamma \mathrm{B}$ 装置を用いた，測定条件は線源 $\mathrm{Cu} K \alpha(\lambda=1.54 \AA)$ 線, $50 \mathrm{kV} 200 \mathrm{~mA}$ で, 幅 $0.2 \mathrm{~mm}$, 長さ 12 $\mathrm{mm}$ のラインスリットを用い, $25^{\circ} \mathrm{C}$ 環境下, $0.2^{\circ}$ から $2^{\circ}$ を 0.08 間隔で, 高角度側における散乱強度が弱いことによる変動 が起こらないことを確認した上で，それぞれ 4 秒間シンチレー ションカウンターで計測した.ここで, 散乱強度の補正は, ガラ ス管と溶媒からの散乱を差し引いたほかは行わなかった。 また， すべてのSAXS 強度は相対值として表した。

\subsection{OXRD によるムライト転化率の測定}

\section{(1) 乾燥ゲル試料の恒温熱処理}

粉末 $2.0 \mathrm{~g}$ を，白金るつほに入れ，これを $600 \pm 1{ }^{\circ} \mathrm{C} に$ 温度調節 された電気炉で10分間処理を行い，水及び有機物などの揮発成 分をあらかじめ除去した．その後950-1050土1 ${ }^{\circ} \mathrm{C}$ 所定の温度 に調節された電気炬にて15分から24時間の所定時間処理を行い， 室温中に取り出した。ここで，るつほを入れた際電気炉の温度が 低下するため, 炬内の温度が所定の温度に復㷌し安定した時点よ り処理時間の計測を開始した. 多くの場合この復㷌には $1-2$ 分 を要した.

(2) QXRD 測定

転化率の測定は，SAXS 測定に用いたのと同様の装置を用い， $50 \mathrm{kV}, 200 \mathrm{~mA}$ の $\mathrm{CuK} \alpha$ を線源とし，結晶化したアルミナの $\mathrm{wt} \%$ として求めた。測定用試料の作製方法に関しては Klug, Alexanderの方法に従った ${ }^{11)}$ 。ここで，アルミナ転化率の wt\% の求めかたについては，まず，ある特定の反射ピークに関し，実 際観測されたピーク面積からベースライン面積を差し引いた面積 值を，あらかじめ作製しておいたそのピーク面積とアルミナ wt\%との検量線に照合することにより行った．本測定における 誤差は $\pm 2 \mathrm{wt} \%$ 程度であった。

\section{3 結果及び考察}

\section{1 溶液濃縮過程の SAXS 測定による溶液構造の比較}

図 2 及び図 3 に，それぞれ NCS 溶液びNS 溶液の, 調液時か ら濃縮することにより紡系可能濃度溶液になるまでの各濃度での， SAXS 測定より得られた実測散乱強度 $I(q)$ の対数值 $(\log I(q))$ と, 散乱ベクトル $q(q=4 \pi(\sin \theta) / \lambda, 2 \theta:$ 散乱角, $\lambda: \mathrm{X}$ 線波長 $1.54 \AA)$ の対数值 $(\log q)$ との関係を示す. 得られた線形に関 してはスリット補正の取扱いを行ってはいないため正確な議論は できないが8)，この図より定性的に下記のことがわかる．溶夜を 構成する粒子の大きさに関する分布を見た場合，NCS 溶液の場 合，調液時の溶液では大きな粒子と小さな粒子に対する分布量の 差は大きく，加熱濃縮することによりその差は小さくなってい 
る.これに対し, NS 溶液の場合, 加熱濃縮により若干その差は 小さくなっているものの, 調液時の分布とそれほど変わらないこ とがわかる.

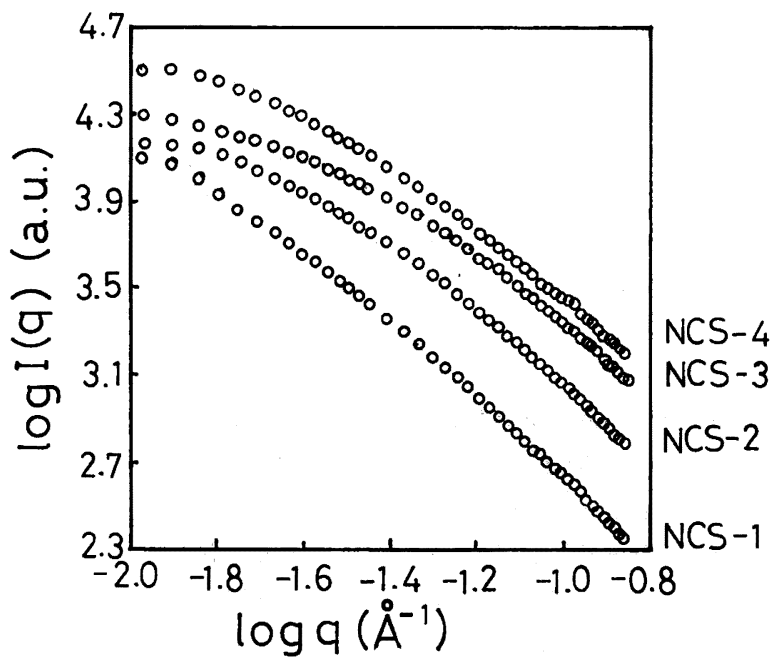

Fig. 2 SAXS actual intensity (a.u.) as a function of the scattering vector $q\left(\AA^{-1}\right)$ of NCS solutions $\left(\mathrm{Al}\left(\mathrm{OPr}^{i}\right)_{3}-\mathrm{Al}\right.$ $\left(\mathrm{NO}_{3}\right)_{3}$-citric acid- $\mathrm{H}_{2} \mathrm{O}$ system, $\mathrm{Al}\left(\mathrm{OPr}^{i}\right)_{3} \mathrm{~mol} / \mathrm{Al}$ $\left(\mathrm{NO}_{3}\right)_{3} \mathrm{~mol}=2, \mathrm{H}_{2} \mathrm{O} \mathrm{mol} /$ total $\mathrm{Al} \mathrm{mol}=50$, total $\mathrm{Al}$ $\mathrm{mol} /$ citric acid $\mathrm{mol}=10$ ) concentrated from as-prepared to viscous spinnable one plotted in a log-log scale

NCS $-1: 0.023 \mathrm{Alg} / \mathrm{sol.g}, \mathrm{NCS}-2: 0.045 \mathrm{Alg} / \mathrm{sol.g}$, NCS $-3: 0.065 \mathrm{Alg} / \mathrm{sol.g}, \mathrm{NCS}-4: 0.095 \mathrm{Alg} / \mathrm{sol.g}$

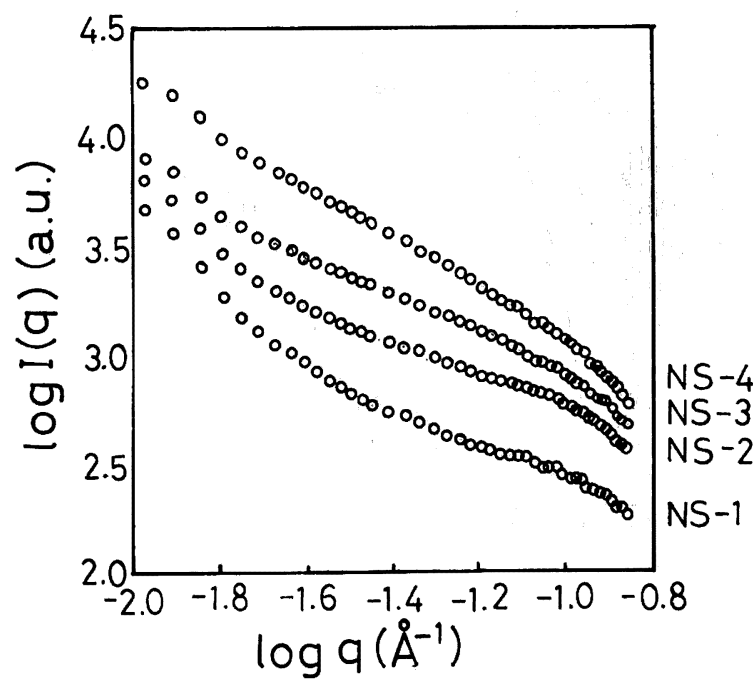

Fig. 3 SAXS actual intensity (a.u.) as a function of the scattering vector $q\left(\AA^{-1}\right)$ of $\mathrm{NS}$ solutions $\left(\mathrm{Al}\left(\mathrm{OPr}^{i}\right)_{3}\right.$ $\mathrm{Al}\left(\mathrm{NO}_{3}\right)_{3}-\mathrm{H}_{2} \mathrm{O}$ system, $\mathrm{Al}\left(\mathrm{OPr}^{i}\right)_{3} \mathrm{~mol} / \mathrm{Al}\left(\mathrm{NO}_{3}\right)_{3} \mathrm{~mol}$ $=2, \mathrm{H}_{2} \mathrm{O} \mathrm{mol} /$ total $\mathrm{Al} \mathrm{mol}=50$ ) concentrated from asprepared to viscous spinnable one plotted in a log-log scale

NS-1 : $0.024 \mathrm{Alg} /$ sol.g, NS $-2: 0.040 \mathrm{Alg} / \mathrm{sol.g}$, NS $-3: 0.055 \mathrm{Alg} / \mathrm{sol.g}, \mathrm{NS}-4: 0.088 \mathrm{Alg} / \mathrm{sol} . \mathrm{g}$
図 4 及び 5 に，それぞれ NCS 溶液及びNS 溶液の, 調液時か ら濃縮することにより紡系可能濃度溶液になるまでの各洪度での， SAXS 測定より得られた実測散乱強度の自然対数値 $(\ln I(q))$ と, 散乱べクトル $q$ の二乗值 $\left(q^{2}\right)$ との関係を示す.

一般的に系が，希䔦な溶液中に十分に分散された粒子より成る 場合，低角度側(Guinier 領域）におけるX 線散乱強度は下記式 で示される Guinier 則に従う9).

$$
I(q)=N(\Delta \rho)^{2} V^{2} \exp \left(-1 / 3 R_{\mathrm{g}}^{2} q^{2}\right)
$$

ここで， $N$ は体積 $V$ 当たりの粒子数を，また， $R_{\mathrm{g}}$ は粒子の慣 性半径を示す.この関係は $q \cdot R_{\mathrm{g}}<1$ において成り立つ. したが

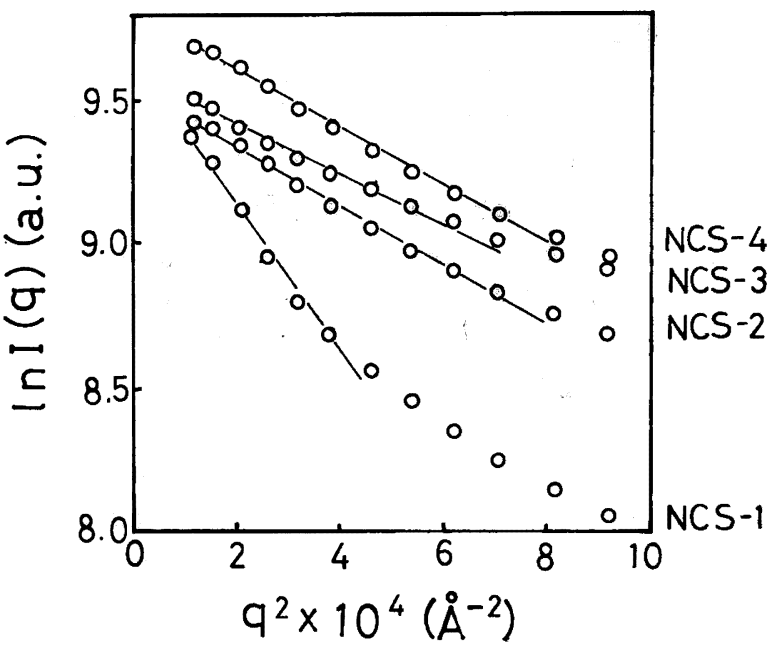

Fig. 4 Guinier' plot of solution obtained in the concentration process of NCS solution from as-prepared to spinnable viscous one (see caption in Fig. 2)

NCS $-1: 0.023 \mathrm{Alg} / \mathrm{sol.g}$, NCS $-2: 0.045 \mathrm{Alg} / \mathrm{sol.g}$, NCS $-3: 0.065 \mathrm{Alg} / \mathrm{sol.g}, \mathrm{NCS}-4: 0.095 \mathrm{Alg} / \mathrm{sol.g}$

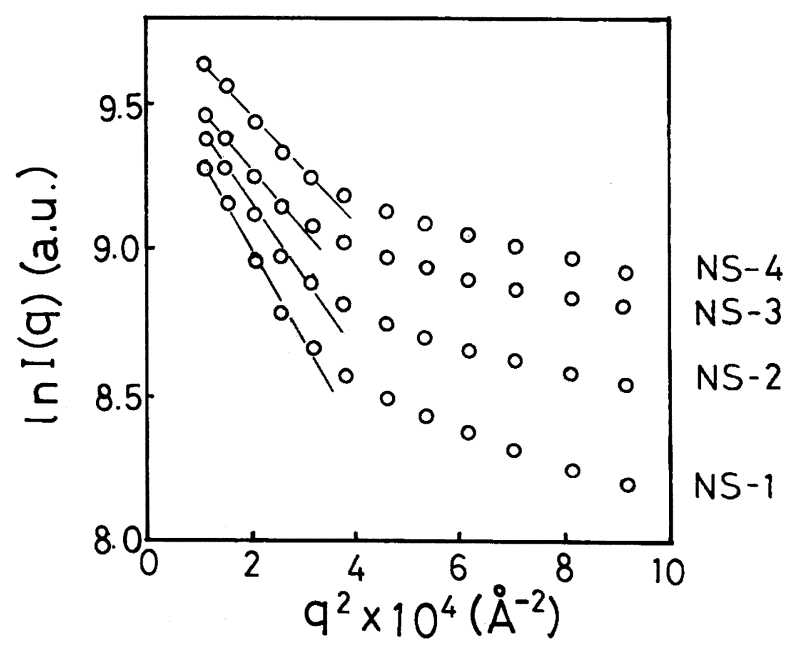

Fig. 5 Guinier' plot of solution obtained in the concentration process of NS solution from as-prepared to spinnable viscous one (see caption in Fig. 3 )

NS- $1: 0.024 \mathrm{Alg} / \mathrm{sol.g}, \mathrm{NS}-2: 0.040 \mathrm{Alg} / \mathrm{sol} . \mathrm{g}$, NS $-3: 0.055 \mathrm{Alg} / \mathrm{sol.g}, \mathrm{NS}-4: 0.088 \mathrm{Alg} / \mathrm{sol.g}$ 
って, Gauss 関数に従う領域での Guinier プロット $(\ln I(q)$ 対 $\left.q^{2}\right)$ の直線の㑯きより $R_{\mathrm{g}}$ を求めることができる.なお，ここに は示していないか，エタノールによる希釈倍率を増大させた試料 につき同様な測定を行ったところ, 㴤度低下による散乱強度の低 い側への曲線のシフトが観察されたものの, 得られた線形は同一 であったここことより，湘定に用いた試料は十分希薄系である と考えられた10).

この様にして得られた NCS 及びNS 溶液に関し, 調夜時から

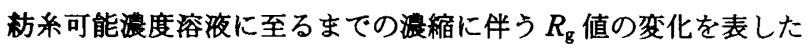
むのが図 6 である．これより，NCS 溶液の場合調液時約 $90 \AA$ で あった $R_{\mathrm{g}}$ 值が，濃縮と共に約 $50 \AA$ まで低下していくのがわか る. また, NS 容夜の場合調夜時約 130 Aであったものが, 濃縮 と共に約 $100 \AA$ まで低下していくのがわかる. この様に何れの溶 夜の場合も浱縮に伴いその $R_{\mathrm{g}}$ 值は低下しているが，その割合は クエン酸を含むNCS 溶夜の方がクエン酸を含まないNS 溶液よ り大きかった。 また, 調液時での $R_{\mathrm{g}}$ 值は, NS 溶液が NCS 溶液 の約1.4倍, 紡系可能浱度溶液まで漫縮された場合の同值は約 2 倍大きな值であった.この様に，クエン酸の添加効果は, 溶液中 に形成される Al クラスターを小さくすると共に, 溶液を構成す る粒子の大きさの分布における差異を小さくすることであると考 えられる.

この様に，ANに対するAIPの量が同一であっても，系にク エン酸を添加した場合と添加しなかった場合で, 溶液を構成して いると考えられる $\mathrm{Al}$ のラスター構造が異なると共に, その後 の濃縮に対する容液構造の変化に対しても異なった挙動を示すこ とがわかった.

\section{$3.2 a$-アルミナの結晶化速度による前駆体構造の比較}

上述したように, クエン酸添加系と無添加系では, 紡系可能濃 度容液における $R_{\mathrm{g}}$ 值が大きく異なると共に，溶液を構成する粒 子の大きさの分布む異なるため, これらの溶液から得られるゲル もこの様な溶液構造を反映すると考えられ，その構造が異なるこ とが予想される. また, 炭素量む異なるため, この様なゲルから 熱処理により $\alpha$-アルミナを得るための結晶化速度に対してむ何 らかの影響があるむのと考えられる.この点を検討するために， それぞれNCS 溶液及びNS 溶液より得られた乾燥ゲル NCS 試

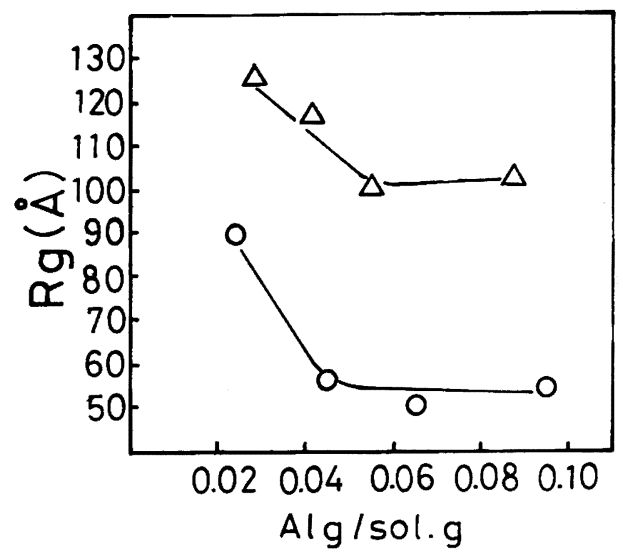

Fig. 6 Change of radius of gyration $\left(R_{\mathrm{g}}\right)$ accompanied with concentration of NCS (see caption in Fig. 2) and NS (see caption in Fig. 3) solutions
料及びNS 試料につき，佰温熱処理での定量的 X 線回折 （QXRD）測定を行った。なお，ここには示していないがNCS 試料及び NS 試料何れの場合も, $700^{\circ} \mathrm{C}$ から $1100{ }^{\circ} \mathrm{C}$ 各 1 時間の

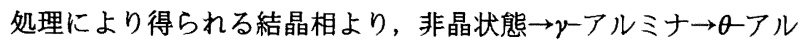

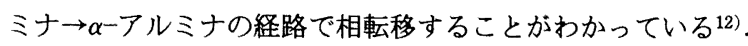

図 7 に各温度での, 処理時間に対する定量的な結晶化率の変 化を, NCS 試料と NS 試料で比較して示す. 何れの曲線も処理 時間に対し, S 字を描くように $\alpha$-アルミナの結晶化率が増大す ることより，次式(2)で示される，核形成一成長に関する Avra$\mathrm{mi}$ モデルに従うと考えられる13) 16).

$$
x=1-\exp \left[-K \cdot t_{\mathrm{ann}}{ }^{n}\right]
$$

式(2)は, 式(3)の様に書き換えられる.

$$
\ln \ln (1 / 1-x)=\ln K+n \ln t_{\mathrm{ann}}
$$

ここで, $x$ は $\alpha$-アルミナへの転換率, $K$ は速度定数, $t_{\mathrm{ann}}$ は実 熱処理時間であり, $n$ は核形成一成長様式で決まる指数 (Avrami 指数）である. NCS 試料及びNS 試料は何れの場合も, $\ln \ln (1 /$ $1-x)$ 対 $\ln t_{\mathrm{ann}}$ のプロットにおいて直線が得られた. しかし,

図 7 より何れの場合も結晶化のための誘導期間が観察されたこ とより，式(3)で得られた直線を $2 \mathrm{wt} \%$ まで外挿することにより 誘導期間 $\left(\tau_{\text {inc }}\right)$ を求めた ${ }^{14), 17), 18)}$ 。ここで，2wt\%としたのは QXRD での精度が \pm 2 wt\%であるためである。これより得られ た誘導期間を表 1 に示す．この表より，NCS 試料における誘導 期間は，NS 試料の場合より若干短いことがわかった．これは， SAXS 測定で示された $R_{\mathrm{g}}$ 值及び粒子の大きさの分布に関する結 果より以下の様に考えられる. NCS 溶液つまりクエン酸を含む 溶液系は NS 溶液に比べ $R_{\mathrm{g}}$ 值が小さく，また，実測散乱強度の 対数值と散乱ベクトルの対数值との関係より得られた曲線より, 構成粒子の大きさにおいて大きな粒子と小さな粒子の分布におけ

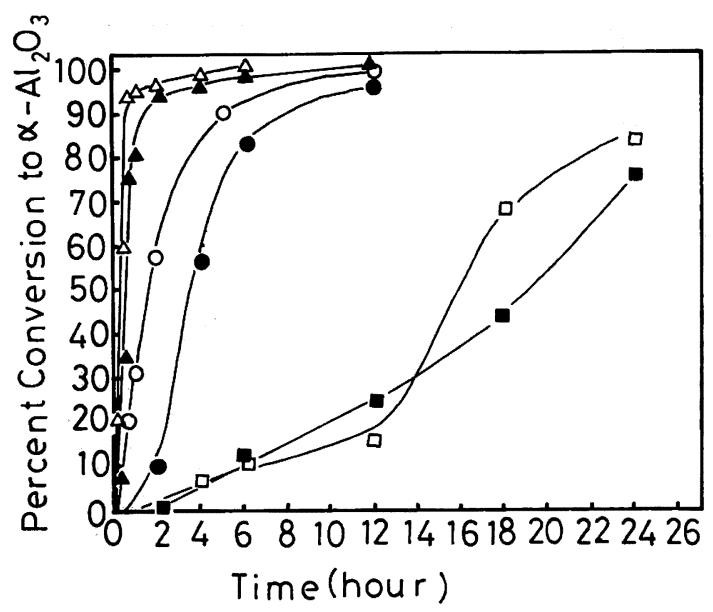

Fig. 7 Isothermal $\alpha$-alumina transformation curves of NCS and NS gel specimens as a function of time. Open symbols designate NCS specimen, and closed symbols NS specimen

NCS specimen (the dried gel specimen obtained from $\mathrm{Al}\left(\mathrm{OPr}^{i}\right)_{3}-\mathrm{Al}\left(\mathrm{NO}_{3}\right)_{3}$-citric acid- $\mathrm{H}_{2} \mathrm{O}$ system, see caption in Fig. 2)

$\mathrm{NS}$ specimen (the dried gel specimen obtained from $\mathrm{Al}$ $\left(\mathrm{OPr}^{i}\right)_{3}-\mathrm{Al}\left(\mathrm{NO}_{3}\right)_{3}-\mathrm{H}_{2} \mathrm{O}$ system, see caption in Fig. 3)

$\square, \square: 950{ }^{\circ} \mathrm{C}, \bigcirc, \bigcirc: 1000{ }^{\circ} \mathrm{C}, \triangle, \Delta: 1050{ }^{\circ} \mathrm{C}$ 
Table 1 Incuvation times in isothermal heat-treatment of NCS and NS gel specimens estimated by the extrapolation of $\ln \ln (1 / 1-\alpha)$ vs. $\ln t_{\mathrm{an} n}$ plot to $2 \mathrm{wt} \% \alpha$-alumina for various annealing temperatures. (see caption in Fig.7)

\begin{tabular}{ccc}
$\begin{array}{c}\text { Temperature } \\
\left({ }^{\circ} \mathrm{C}\right)\end{array}$ & \multicolumn{2}{c}{ Incuvation time $(\mathrm{h})$} \\
& NCS & NS \\
\hline 950 & 1.64 & 2.03 \\
1000 & 0.31 & 0.73 \\
1050 & 0.07 & 0.10
\end{tabular}

る差異が小さいことが示されていることから，NCS 溶液は NS 溶液に比へ比較的小さなクラスターから構成されていると考えら れる．また，NCS 溶液の場合，この様なクラスター間にクエン 酸が配位していると考えられる。そして，この様な溶液構造は， 溶液がゲル化することにより得られた各 NCS 試料及びNS 試料 中にも反映されると考えられる，つまり，溶液で見られた様な $\mathrm{Al}$ クラスター構造を一つの単位として，これが分解・再結合を 行いながら濃縮されていく，更に濃縮が進み，クラスター同士の 相互作用が強くなり，また，新たな結合を形成することによりゲ ル化が起こると考えられる．したがって，この様なゲル化構造の 中には粘度が上昇した溶夜中で見られた様な構造が，若干変化は しているものの保持されると考えられる. そして, 乾燥での水分 除去によりクラスター間に存在する水分子の状態は変化するが, 基本的には乾燥ゲル試料中にも，この様な構造は受け継がれると 考えられる.したがって， NCS 試料は，Al クラスター構造を単 位とする，より小さな粒子構造の集合体より形成されていると考 えられる.この様な構造には構造不整の位置が多数存在し，これ を熱処理した場合, 熱分解反応による分解核が発生し易く ${ }^{19)}$, したがって、これが起点となり結晶転移による $\alpha$ ーアルミナ相生 成の誘導期間が短くなったと考えられる．更に，以前著者らが報 告したように, NCS 溶液の場合, 紡系可能濃度溶液は六配位 $\mathrm{Al}$ の構造をとるのに対し，NS 溶液の場合，ある程度四配位 $\mathrm{Al}$ も 含むような構造をとる ${ }^{2)}$.この構造も乾燥ゲル試料に反映されて いると考えられ20), この様な乾燥ゲル試料中に存在する四配位 $\mathrm{Al}$ 構造は $1200^{\circ} \mathrm{C}$ 程度の高温で処理した場合も残留することが報 告されていることより ${ }^{21)}$, NS 試料の場合熱処理に伴う $\alpha$-アル ミナの前駆体相への配位数変換を含む相転移を遅延させるように 働いているのではないかと考えられる．これらに対し，ムライト

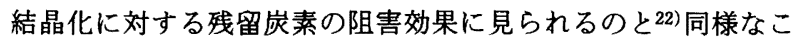
とがアルミナの場合にも考えられるとすると,クエン酸を含む $\mathrm{NCS}$ 試料の場合，NS 試料に比へ残留炭素の影響が大きく，し たがって， $\alpha$-アルミナの結晶化が阻害されると考えられるが, この効果を差し引いたとしても上記に示したような核の形成がよ り有効に働いたと考えられる.

次に， $\alpha$-アルミナの核形成・成長プロセスが誘導期間の後起 こると仮定すると，実熱処理時間 $\left(t_{\mathrm{ann}}\right)$ 加ら誘導期間 $\left(\tau_{\mathrm{inc}}\right)$ を差 し引いた時間 $t_{\mathrm{m}}\left(t_{\mathrm{m}}=t_{\mathrm{ann}}-\tau_{\mathrm{inc}}\right)$ に式(3)を書き換えることにより 式(4)が得られる.

$$
\ln \ln (1 / 1-x)=\ln K+n \ln t_{\mathrm{m}}
$$

$\mathrm{NCS}$ 試料及び NS 試料からは $\ln \ln (1 / 1-x)$ 対 $\ln t_{\mathrm{m}}$ プロット することにより直線関係が得られ， $n$ 值は共に1.6であった。こ
こで，本論文において示される温度で佰温熱処理し定量的 $\mathrm{X}$ 線 回折測定を行った際， $\alpha$-アルミナ以外に観察される回折ピーク は何れの場合も $\theta$ アルミナであった．したがって，本論文の場

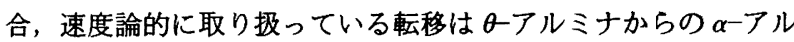
ミナ相への転移と考えることができ， $n$ 値はこの過程を反映した

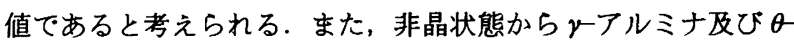
アルミナを経由し $\alpha$-アルミナ核形成に至る転移の速度論に関し ては複合的な転移として，また，上記において示されるように晞 燥ゲル構造を反映しながら誘導期間 $\left(\tau_{\text {inc }}\right)$ に反映されたものと考 えられる.ここで，本論文において得られた $n$ 值はバイエライ 卜を出発原料とし，これをあらかじめ500 ${ }^{\circ} \mathrm{C} \cdot 2$ 時間処理したと

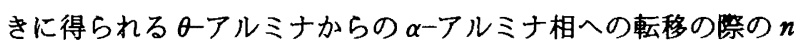
值と同一であった ${ }^{13)}$ ：この様に，核形成一成長に関する様式は これらの試料に関して同一であることが示された．また，これよ り得られる速度定数 $K$ の自然対数值 $(\ln K)$ と $1 / T$ の Arrhenius プロットより, NCS 試料については $473 \pm 10 \mathrm{~kJ} / \mathrm{mol}$, また, NS 試料については $452 \pm 10 \mathrm{~kJ} / \mathrm{mol}$ の見かけの活性化エ ネルギー $(\Delta E)$ を得た。

反応速度定数と $1 / T$ との Arrhenius プロットより得られた活 性化エネルギー $(\Delta E)$ で, NCS 試料より得られた値が NS 試料 より得られた値より若干大きい理由については次のように考える ことができる，つまり，上述したような乾燥ゲル試料における構 造の違いより，NCS 試料の場合，NS 試料の場合に比較して小 さな，単独した前駆体粒子が熱処理により形成されるのではない かと考えられる.この様な独立した小さな粒子が成長しようとす る場合，より多くの粒界における障壁を乗り越えて成長する必要 があり，したがって，NCS 試料で示される活性化エネルギ一值 が NS 試料で示される值より若干大きくなったと考えられる.

\section{4 結論}

アルミナ前駆体紻維を得るための溶液系

(1) $\mathrm{NCS}$ 溶液 : $\mathrm{Al}\left(\mathrm{OPr}^{i}\right)_{3}-\mathrm{Al}\left(\mathrm{NO}_{3}\right)_{3}$-クエン酸 $-\mathrm{H}_{2} \mathrm{O}$ 系

(2) NS 㴼: $\mathrm{Al}\left(\mathrm{OPr}^{i}\right)_{3}-\mathrm{Al}\left(\mathrm{NO}_{3}\right)_{3}-\mathrm{H}_{2} \mathrm{O}$ 系,

に関し，クエン酸の有無が，溶液構造に如何なる影響を与える のかをSAXS 測定より，また，得られたゲル試料を焼成した場 合の $\alpha$ ーアルミナへの結晶化速度を QXRD 測定により検討したと ころ以下の結果を得た.

(1) NCS 溶液の $R_{\mathbf{g}}$ 值は NS 溶液のそれよりも小さかった． た, NCS 溶液及びNS 溶液何れの溶液の場合も濃縮に伴いその $R_{\mathrm{g}}$ 值は低下したが，その割合はクエン酸を含む NCS 溶液の方が クエン酸を含をないNS 溶液より大きかった。このことから， ANに対するAIPの量が同一であっても，系にクエン酸を添加 した場合と添加しなかった場合で，溶液を構成していると考えら れる $\mathrm{Al}$ のクラスター構造が異なると共に，その後の濃縮に対す る溶液構造の変化に対しても異なった挙動を示すことが明らかと なった。

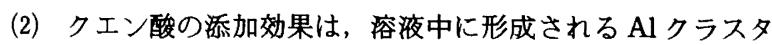
一を小さくすると共に，溶液を構成する粒子の大きさの分布にお ける差異を小さくすることであることが示された.

(3) 誘導期間は NCS 試料の方が NS 試料より短く，これは溶 液構造を反映した乾燥ゲル試料を熱処理した場合，より小さな粒 子構造よりなる NCS 試料には構造不整の位置が多数存在し, 熱 
分解反応による分解核が発生し易く, 残留炭素による結晶化阻害 効果の分差し引かれるものの, 発生した核が起点となり結晶転移 が容易に起こったためと考えられる.

(4) 誘遷期間を差し引いた時間と転換率との間で成り立つ Avrami 式は $\theta$-アルミナからの $\alpha$-アルミナ相への転移を示して いると考えられ，これより得られる指数は何れの試料においても 1.6であり,クエン酸の有無及び容液構造を反映すると考えられ ろ試料における構造の違いは，核形成一成長の様式には影響しな いことがわかった。

（5） 反応速度定数と $1 / T$ との Arrhenius プロットより得られ た活性化エネルギー值は，NCS 試料のそれが NS 試料のそれよ り若干大きかった。これは試料における構造を反映し, NCS 試 料の場合, NS 試料の場合に比較して小さな単独した前駆体粒子 が熱処理により形成されることが原因ではないかと考えられた。

この様に, アルミナ前駆体緎維を得るための溶液系において, クエン酸添加の有無は溶液構造に大きな差異を与えることが示さ れた．また，乾燥ゲル試料を熱処理した場合の結晶化挙動（誘導 期間, 活性化エネルギ一) はクエン酸添加系及び無添加系の場合 で異なり，これは炭素含有量の違い以上に溶液構造における違い を反映した乾嬠ゲル試料での差異が原因であると考えられた.

\section{傠辞}

SAXS 测定及び QXRD 測定に協力いただたた株式会社ユニチ カリサーチラボの鹿島 腾氏及び西谷浩之氏に感謝する.

1）西尾俊幸, 藤木良規, 日本セラミックス協会学術論文誌, 98, 1223(1990).

2）西尾俊幸，藤木良規，日化，1991，1346。
3）西尾俊幸, 藤木良規, 日化, 1991, 1355 .

4) 西尾俊幸, 藤木良規, 日本セラミックス協会学術論文誌, 100, 815(1992).

5) T. Nishio, Y. Fujiki, J. Mater. Sci. Lett., 12, 394(1993)

6) D. W. Schaefer, K. D. Keefer, Phy. Rev. Lett., 53, 1383(1984).

7) C. J. Brinker, K. D. Keefer, D. W. Schaefer, R. A. Assink, B. D. Kay, C. S. Ashley, J. Non-Cryst. Solids, 63, 45(1984).

8）高分子学会高分子実験学編集委員会編, 高分子実験学, 17, “高分子の固体構造 II” 共立出版 (1984) p. 128.

9) O. Glatter, O. Kratky, "Small Angle X-Ray Scattering", Academic Press, New York (1982).

10) W. V. Rausch, H. D. Bale, J. Chem. Phys., 40, 3391(1964).

11) H. P. Klug, L. K. Alexander, "X-Ray Diffraction Procedures", John Wiley \& Sons, New York (1954) p. 297-304.

12）西尾俊幸, 鹿島 勝, 藤木良規, J. Mater. Sci., 印刷中

13） J. R. Wynnyckyj, C. G. Morris, Metall. Trans. B, 16B, 345(1985).

14) R. A. Shelleman, G. L. Messing, M. Kumagai, J. NonCryst. Solids, 82, 277(1986).

15）大門啓志, 加藤悦朗, 墨業協会誌, 94, 273(1986)

16）林浩一, 豊田誠司, 武部博倫, 森永健次, 日本セラミ ックス協会学術論文誌, 99, 550(1991).

17) W-C. Wei, J. W. Halloran, J. Am. Ceram. Soc., 71, $581(1988)$.

18) S. J. Wilson, J. D. C. MC Connell, J. Solid State. Chem., 34, 315(1980).

19）林 浩一, 豊田誠司, 中島邦彦, 森永健次, 日本セラミ ックス協会学術論文誌, 98, 444(1990).

20) M. S. Lizer, S. Pawlowski, "High Tech Ceramics", Elsevier Science (1987) p. 2327-35.

21) B. E. Yoldas, Mat. Res. Soc. Symp. Proc., 24, 291(1984).

22) D. X. Li, W. J. Thomson, J. Am. Ceram. Soc., 73, 964(1990) 


\title{
Comparison of $\alpha$-Alumina Crystallization Behavior in the Solution Method between with and without the Addition of Citric Acid
}

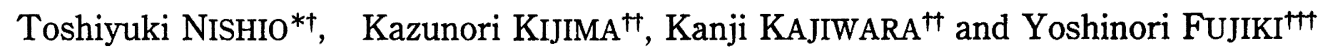 \\ Central Research Laboratories, UNITIKA Ltd.; 23, Uji Kozakura, Uji-shi 611 Japan \\ †Present address: UNITIKA Ltd.; 5, Uji tonouchi, Uji-shi 611 Japan \\ "Department of Chemistry and Materials Technology, Kyoto Institute of Technology; \\ Matsugasaki, Sakyo-ku, Kyoto-shi 606 Japan \\ "National Institute for Research in Inorganic Materials; 1-1, Namiki, \\ Tsukuba-shi 305 Japan
}

Concerning to the solution to obtain alumina precursor fiber, i.e., (1) NCS solution: $\mathrm{Al}\left(\mathrm{OPr}^{i}\right)_{3}$ $\mathrm{Al}\left(\mathrm{NO}_{3}\right)_{3}$-citric acid- $\mathrm{H}_{2} \mathrm{O}$ system $\left(\mathrm{Al}\left(\mathrm{OPr}^{i}\right)_{3} \mathrm{~mol} / \mathrm{Al}\left(\mathrm{NO}_{3}\right)_{3} \mathrm{~mol}=2, \mathrm{H}_{2} \mathrm{O} \mathrm{mol} /\right.$ total $\mathrm{Al} \mathrm{mol}=50$, total $\mathrm{Al} \mathrm{mol} /$ citric acid mol $=10)$, and (2) NS solution: $\mathrm{Al}\left(\mathrm{OPr}^{i}\right)_{3}-\mathrm{Al}\left(\mathrm{NO}_{3}\right)_{3}-\mathrm{H}_{2} \mathrm{O}$ system $\left(\mathrm{Al}\left(\mathrm{OPr}^{i}\right)_{3} \mathrm{~mol} /\right.$ $\mathrm{Al}\left(\mathrm{NO}_{3}\right)_{3} \mathrm{~mol}=2, \mathrm{H}_{2} \mathrm{O} \mathrm{mol} /$ total $\mathrm{Al} \mathrm{mol}=50$ ), it was investigated how the addition of citric acid affected the solution structure by small angle X-ray scattering measurement(SAXS). Crystallization kinetics of $\alpha$-alumina by heating of the gel specimens obtained from these solutions was investigated using quantitative X-ray diffraction (QXRD) measurement. The radius of gyration $\left(R_{\mathrm{g}}\right)$ obtained from SAXS measurement decreased accompanying concentration from as-prepared solution to spinnable one in both NCS and NS solutions. The $R_{\mathrm{g}}$ of former solution was $50 \AA$, and latter's was $100 \AA$ in the concentrated spinnable solution. The structure change of $\mathrm{Al}$ clusters in the solution accompanying concentration was affected with or without addition of citric acid even if the molar ratio of $\mathrm{Al}\left(\mathrm{OPr}^{i}\right)_{3}$ to $\mathrm{Al}\left(\mathrm{NO}_{3}\right)_{3}$ was the same in both solutions. It was shown by QXRD measurement that NCS specimen had shorter incubation period than NS specimen in isothermal heat-treatment at $950,1000^{\circ} \mathrm{C}$ and $1050^{\circ} \mathrm{C}$. Activation energy of NCS specimen obtained from the Arrhenius plot of $1 / T$ (absolute temperature) and rate constant obtained from Avrami equation were slightly larger than those of NS specimen. These phenomena were considered to be caused by the differences in structure of dried gel specimens, which reflected the differences of carbon quantity and that of cluster structure in solutions resulting from with or without the addition of citric acid. The Avrami exponents were 1.6 in both specimens. The differences in structure of specimens, which is supposed to reflect the difference in solution structures between with or without citric acid, does not affected the nucleation and growth mode. 